九州大学学術情報リポジトリ

Kyushu University Institutional Repository

\title{
Considerations of Thunder Magic Rituals and Thunder Divinities
}

Reiter, Florian C.

Humboldt University : Professor

https://doi.org/10.5109/1654565

出版情報：Journal of Asian Humanities at Kyushu University. 1, pp.9-18, 2016-03. Kyushu University, School of Letters, Graduate School of Humanities, Faculty of Humanities バージョン:

権利関係 : 


\section{Considerations of Thunder Magic Rituals and Thunder Divinities}

\author{
FLORIAN C. REITER
}

ODERN western studies of Daoist religion convey the notion that the appearance and existence of Chinese divinities oscillate between being bright and sinister, between good and bad, especially if the divinities had originally been active in this world and were then seen in their posthumous lives as divine, with possibly demoniac elements. Literary works and entertaining descriptions of extraordinary phenomena (chuanqi xiaoshuo 傳奇小說), such as the sixteenth-century Investiture of the Gods (Fengshen yanyi 封神演義), constitute entertaining source materials that seem to reflect widely known popular ideas. Some of the spirit forces we read about were allegedly humans who underwent a spiritual refinement through the help of higher divinities or through support given by Daoist priests. ${ }^{1}$ The Daoist priests represent Heavenly Masters of Daoism (Tianshi dao 天師道), also known as Cheng-i Daoism (Zhengyi dao 正一道) or Daoism of Orthodoxy and Unity.

1 A notorious example is the deity Prince No Zha taizi (那叱太子), see Wilhelm Grube, Die Metamorphosen der Götter (Leiden, E.J. Brill, 1912), 156. Also see J. Chamberlain, Chinese Gods (Hong Kong: Long Island Publishers, 1983), 89; and Kubo Noritada, Daojiao zhushen (Chengdu: Sichuan renmin chubanshe, 1996), 146.
Heavenly Masters Daoism emerged in the second century of the Han period (206 BCE-22O CE) and thrives until today. The divine addressees of the liturgy in Heavenly Masters Daoism are first of all the divinities that represent the abstract and highest echelon of the divine constituted by the Three Pure Ones (sanqing 三清). They include the Heavenly Worthy of Prime Origin (Yuanshi tianzun 元始天尊), the Heavenly Worthy of the Numinous Jewel (Lingbao tianzun 靈寶天尊), and the Heavenly Worthy of Dao and its Virtue (Daode tianzun道德天尊), the latter being the deified author of the Daode jing 道德經 who was also known as the Supreme Lord Lao (Taishang Laojun 太上老君). In fact, the two divine worthies Prime Origin and Numinous Jewel are believed to be transformations of Taishang Laojun who incorporated the absolute, cosmic being. ${ }^{2}$ The Three Pure Ones are the supreme authorities and objects of veneration in the Daoist grand communal and public festivities or offerings (jiao 醮). However, the priests of Heavenly Masters Daoism also served

2 Florian C. Reiter, transl./ed., Leben und Wirken Lao-Tzu's in Schrift und Bild, Lao-chün pa-shih-i-hua t'u-shuo (Würzburg: Königshausen \& Neumann, 1990), 21. Also see TT 774 Youlong zhuan 1.6a-6b; and TT 772 Taishang Laojun jinshu neixu 2b. 
the daily needs of an agrarian society, where droughts, floods, and epidemics were constant problems. Such plagues and also the concerns of individual people who suffered from illness and other private problems were explained with demoniac interference. The priest of Heavenly Masters Daoism had exorcist ways and means to tackle this type of issue. He employed a different set of divine addressees that represented the forces of nature such as wind and fire, thunder and lightning, that were seen as martial forces with spirit generals and marshals. The priest of Heavenly Masters Daoism could isolate and trap them in amulets, which came to be most important ritual tools in Daoist exorcism that we call Thunder Magic rituals.

The term Thunder Magic rituals (leifa 雷法 / wulei $\mathrm{fa}$ 五雷法) has since the Song period (eleventh century) has summarized the confusion of these Daoist exorcist rituals that pertain to practical concerns of daily life. ${ }^{3}$ In the Song period some outstanding priests and scholars such as Wang Wenqing (王文卿, 1093-1153) followed the intellectual tendency of the time and formulated theories to explain the enactment of Thunder Magic rituals and the drafting of amulets, which were called Thunder amulets. ${ }^{4}$ Nowadays Daoist exorcist rituals are often performed by priests at their home altars where the term minor ritual (xiaofa shi 小法事) applies. Larger ritual events may be staged in temples and are called ritual arenas (fachang 法場), which we can see, for example in Taiwan. ${ }^{5}$ However, I now focus on

3 See the statements of the $43^{\text {rd }}$ Heavenly Master Chang Yuchu 張宇初 in TT 1311 Xianquan ji 7.13a (Shoufa pushuo 授法普說) 法also see TT 1232 Daomen shigui 11a; and Florian C. Reiter, Grundelemente und Tendenzen des Religiösen Daoismus, das Spannungsverhältnis von Integration und Individualität in seiner Geschichte zur Chin-, Yüan- und Frühen Ming-Zeit (Münchener Ostasiatische Studien 48) (Stuttgart: Steiner-Verl.Wiesbaden, 1988), 37-38.

4 See Florian C. Reiter, Man, Nature and the Infinite, the Scope of Daoist Thunder Magic Rituals (Abhandlungen für die Kunde des Morgenlandes 81) (Wiesbaden: Harrassowitz, 2013), and Florian C. Reiter, "The Discourse on the Thunders 雷說, by the Daoist Wang Wen-ch'ing 王文卿 (1093-1153)," Journal of the Royal Asiatic Society 14/3 (2004), 207-29. See the Tang Daoist Zhang Wanfu 張萬福 in TT 1241 Chuanshou sandong jingjie falu lüeshuo $1.4 a-4 b$.

5 See Lin Zhenyuan, "Le ritual Daoiste du sud-est du Fujian," PhD dissertation (EPHE, 2014), 89-127 (法場). Also see John Keupers, "A Description of the Fa-ch'ang Ritual as Practiced by the Lü Shan Daoists in Northern Taiwan," in Buddhist and Daoist Studies I, edited by Michael Saso and David W. Chappell (Honolulu: University of Hawai'i Press, 1977), 79-94. In Taiwan the term Thunder Magic rituals is not familiar as far as I know. I have learned, however, that the terms and ritual practice are still popular in some historical documents for this study on Thunder Magic rituals and Thunder Divinities, relying partly on literary contributions by Wang Wenqing.

Again, it is important to keep in mind that the essential component of Daoist Thunder Magic rituals is the drafting and application of Thunder amulets (leifu 雷符), crystallize and transmit the might of martial Thunder divinities. The creation of such amulets is an independent ritual process, but their application can be accommodated in the context of larger rituals. These ae documented in literary sources of the later Daoist exorcist tradition of the Daoism of Subtle Tenuity (Qingwei dao 清微道) dating from the Yuan and Ming periods (fourteenth to sixteenth century). ${ }^{6}$

We emphasize that the performing priests thought of themselves as representatives of Heavenly Masters Daoism, performing in accordance with the respective rules and formal requirements. They explicitly venerated the Heavenly Master Zhang Daoling (張道 陵) as their spiritual ancestor; this was their identity when they performed the Daoist offerings (jiao 醮). We notice that canonical sources since the Tang period (seventh to ninth century) do not attest a rigid and rationalized distinction between the two terms Master of the Dao (daoshi 道士) and Master of the Ritual (fashi 法師). The two terms both mean "exorcist priest" in Heavenly Masters Daoism. ${ }^{7}$

In the Song period the Daoist Wang Wenqing was the outstanding Thunder specialist at the court of emperor Song Huizong (宋徽宗 r. 1100-26). Here he performed exorcist Thunder rituals and then staged liturgies of Heavenly Masters Daoism to give thanks for successful exorcisms. Wang Wenqing analyzed and theorized about ancient exorcist practices, which had long been current in Daoist religious practice. He and his colleagues gave literary form to these ancient, largely oral traditions, and applied a new approach, using the

provinces on the Chinese mainland, such as Hunan province.

6 See, for example, TT 223 Qingwei yuanjiang dafa 25.15b-17b (Taishang wuji dadao tianjing 太上無極大道天經). Generally, see chapters $1-50$ of TT 1220 Daofa huiyuan.

7 See TT 1225 Dongxuan lingbao sadong fengdao kejie yingshi 4.6b-8a, which uses the terms "follower" dizi 弟子 and fashi 法 師 to represent different Daoist ranks. Also see Florian C. Reiter, The Aspirations and Standards of Taoist Priests in the Early T'ang Period (Asien- und Afrika-Studien 1 der Humboldt-Universität zu Berlin) (Wiesbaden: Harrassowitz, 1998), 133-37. Also generally see Wu Zhen, Wei shenxing jia zhu, Tang Song Ye Fashan chongbai di zaocheng shi (Peking: Zhungguo shehui kexue chuban she, 2012). 
notions of Internal Alchemy (neidan 內丹), of astronomy and other calculative means to explain the operation of Thunder Magic rituals. I continue on this basis to feature spirit generals, marshals, and emissaries, in short the Thunder divinities (leishen 雷神), and also show how they were made present in Thunder amulets. ${ }^{8}$

The Thunder divinities hold martial ranks and show martial appearances. They often look like fierce birdmen (niaoren 鳥人), with a beak and phoenix claws; wielding weaponry they appear to soar or jump wildly. There are also countless amulets of a different design, combining Chinese characters and graphic symbols such as the eight trigrams (bagua八卦) or other symbols. ${ }^{9}$ The most basic and seemingly simple amulet consists of a single Chinese character. ${ }^{10}$ An excellent example is the Thunder divinity Zhao Gongming Xuantan (趙公明玄壇), or Marshal Zhao (趙元帥), who is one of the protective deities (hufa shen 護法神) at Daoist altars whom we see depicted on the scrolls in the Dao-arena (daochang 道場) when rituals take place. ${ }^{11}$

The surname Zhao 趙 in its assembled form may make up an amulet. The Chinese character can be broken down in order to specify the meaning of each stroke or component. This means that the priest who draws the zhao amulet assembles the strokes of his writing brush while at the same time having a meditative vision as he recites the intrinsic meaning of each part of the character. The Practical Application of the Character Zhao (Zhaozi zuoyong 趙字作用) presents the religious identification of the various graphic components of the character zhao. The text gives key words but rarely a complete sentence. Each of the fourteen statements, some of which are short and some extended, features one single stroke of the brush. It takes fourteen strokes to write the character and surname Zhao 趙:

8 See Chang Yuchu in TT 1311 Xianquan ji 7.13a, concerning the tradition of Qingwei Daoism (清微道). He observes the astonishingly long tradition of toral transmission since Zhang Daoling (Han period) to Zu Shu (祖 舒, Tang period). The crucial importance of oral traditions is usually not taken into account in modern studies of Daoism. Also see Florian C. Reiter, Basic Conditions of Daoist Thunder Magic.

9 See Florian C. Reiter, Man, Nature and the Infinite, the Scope of Daoist Thunder Magic Rituals, 165-68.

10 See below the example of the character zhao 趙.

11 See Florian C. Reiter, "Daoist Thunder Magic (Wu-lei fa), Illustrated with the Example of the Divine Protector Chao Kungming," Zeitschrift der Deutschen Morgenländischen Gesellschaft 160 (2010): 121-54.
/True void: subtle and mysterious (weimiao zhenkong 微妙真空)/Lord Zhao of Shenxiao Heaven (Shenxiao Zhaogong 神霄趙公)/Discharge the Thunders speedily and organize the lightning (qulei chedian 驅雷掣電)/Make fire rage and wind blow (zouhuo xingfeng 走火行風)/Fierce generals of the eight kings (bawang mengjiang 八王猛將) ${ }^{12}$ / Unlimited and divine omnipresence (wuliang shentong 無量神通)/Divine troops, completely unite (shenbing yiho 神兵一合)/Fill all around the empty space (bianman xukong 遍滿虛空)/Which divinity does not comply? (heshen bu fu 何神不伏) ${ }^{13} /$ Which demon dares to oppose? (hegui ganchong 何鬼敢 衝)/Divine tiger, bite them [dead] at once (shenhu yidan 神虎一噉)/All demons have their tracks extinguished (wangui miezong 萬鬼滅蹤)/Orthodoxy and Unity, issue decrees and summons (zhengyi chizhao 正一敕召)/Speedily descend to the central palace (sujiang zhonggong 速降中宮)/ Gongming (Gongming 公明), I respectfully implore: Zhao Gongming speedily let your true magic might descend like fire. urgently, urgently, this is like an order from the Venerable Patriarch the Heavenly Master (jinqing Zhao Gongming huosu jiang zhenling ji-ji ru Laozu Tianshi lüling 謹請趙公明火速 降真靈急急如老祖天師律令 $).{ }^{14}$

The priest honors the proper sequence of the individual strokes of the character zhao and knows by heart these interspersed formulae to write the surname Zhao, which addresses the Thunder deity Zhao Gongming. ${ }^{15}$ The priest commands the deity to appear with all his divine might. The priest does not set out to write the amulet without adopting a divine alter ego, which is the first Heavenly Master Zhang Daoling 張道陵 (Laozu Tianshi 老祖天師). In other words, the priest identifies himself in meditation (cunxiang 存想) with the Heavenly Master.

12 TT 1220: 232.3a-3b. Also compare TT 1220: 236.3a-3b.

13 The word fu (伏) means to fall prostrate and yield. We understand the word in the sense of fushi (伏侍/事) "to wait upon/to serve," see Herbert A. Giles, A Chinese-English Dictionary (Taipei: Cheng Wen Publishing Co., 1972), nr. 3691.

14 TT 1220: 232.13b, in The Secret Rituals of Marshal Zhao at the Heavenly Altar of Orthodoxy and Unity (Zhengyi xuantan Zhao Yuanshuai mifa 正一玄壇趙元帥祕法). The secret rituals were compiled after the time of Wang Wenqing but they are in line with his Daoist tradition. The slashes stand for the single strokes of the writing brush, which are clearly shown in the text.

15 Giles, A Chinese-English Dictionary, nr. 498. 
Exorcist traditions of Thunder Magic usually demand that the priest transforms (bianshen 變神) into a Thunder divinity, which is a most complex process that the priest and scholar Wang Wenqing described in terms of Internal Alchemy. ${ }^{16}$ Many Daoist scholars like Sa Shoujian (薩守堅, fl. 1141-78?) continued in this sense to develop Thunder theories. ${ }^{17}$ However, the short Practical Application of the Character Zhao indicates that the amulet-character zhao (趙) that has a demon-quelling capacity does not require such a demanding transformation.

The majority of Thunder amulets are much more complicated. A magnificent example is the Personal Amulet of Marshal Chao (Zhaoshuai benshen fu 趙帥本 身符), shows a fierce bird-man wielding an iron whip as his weapon. The single components of the amulet are instilled with meanings as follows:

Great Yang, be powerfully active and let the

Golden Wheel appear (taiyang hehe xianchu jinlun 太陽赫赫現出金輪)/

Zhao Gongming (趙公明) ${ }^{18}$ I

Gongming, Gongming, show speedily your true form. (Gongming Gongming suxian zhenxing 公明 公明速現真形 $) /$

Decree ( $c h i$ 敕)/

Respectfully receive the decree from the supreme God-emperors to arrest the wicked spirits (feng shangdi chi shouzhuo xiejing 奉上帝敕收捉邪精)/ Kill (sha 鞄)/

Kill Heaven, kill earth, kill year, kill month, kill day, kill times. Hsüan- $\mathrm{t}^{\prime}$ an presents the order to kill all wicked demons, they must all be killed (tiansha disha niansha yuesha risha shisha Xuantan yuanshuai fengchi sha yiqie xiemo jie shousha 天慜 地䚫年棂月繁日繁時繁玄壇元帥奉敕繁一切邪 魔皆受繁)/

Assistance (she 攝)/

- assist Heaven, assist earth, assist earth, assist heaven. Demons and divinities without Dao, all must be arrested (tianshe dishe dishe tianshe wudao guishen jinjie zhuoshe 天攝地攝地攝天攝 無道鬼神盡皆捉攝)/

田 19 /

Open the Gate of Heaven. Close the Window of Earth. Keep open the Gate of Man. Obstruct the Way of Demons. Pierce the demons' hearts. Crush the demons' bellies (kai tianmen bi dihu liu renmen sai guilü chuan guixin po guidu 開天門閉地戶留 人門塞鬼路穿鬼心破鬼肚)/

With your left [hand] hold the iron whip so as to shake and stir up the cosmos, wind, thunders, lightning, radiance, and rumbling of Thunders that may assist you (zuochi tiebian zhendong qiankun fenglei dianguang pili she 左執鐵鞭震動乾坤風雷 電光霹靂攝)/

With your right [hand] hold up the iron chain and assist as do the fierce spirit troops of the divine twenty-eight stellar divisions. Recollect the complete row of symbols of the twenty-eight stellar divisions (youti tiesuo shezhuo ru ling ershiba xiu menglie jingbing nian ershiba xiu shusuo 右提鐵索 攝捉如靈二十宿猛烈精兵念二十八宿書索)/

On your front side you discharge Thunders and lightning. Behind you, you raise winds and clouds (qianqu leidian houqi fengyun 前驅雷電後起風 雲)/

Tan 貪, $j u$ 巨, $l u$ 祿, wen 文, lian 廉, $w u$ 武, po 破 $2^{20}$

Fierce generals of the eight kings, lead on the cohorts of all the divinities to enter speedily the centre of the amulet, and the response will become clearly manifest (ba wang mengjiang buling zhushen su ru fuzhong baoying fenming 八王猛將 部領 諸神速入符中報應分明)/

Deities of Wind and Fire, you must be extremely fast at chasing and arresting. Act most urgently
16 See Florian C. Reiter, "A Preliminary Study of the Daoist Wang Wen-ch'ing (1093-1153) and his Thunder Magic (lei-fa)," Zeitschrift der Deutschen Morgenländischen Gesellschaft 152 (2002): 155-84, esp. 172 (Assembling the Divine Force), which shows the transformation into the divinity Marshal Deng (Deng Bowen 鄧伯溫), see below.

17 TT 1220: 67.11a-18a (Discourse on the Thunders Leishuo 雷說 by Sa Shoujian).

18 The three characters are in bold print, denoting that Zhao Gongming is the golden wheel. See above his religious titles.
19 The graph resembles the character for the word "field" (tian 田). In fact, the graph combines six strokes of the brush that represent the six statements (Six Instructions liujue 六 訣), see also Florian C Reiter, "The Management of Nature: Convictions and Means in Daoist Thunder Magic (Daojiao leifa)," in Purposes, Means and Convictions in Daoism, A Berlin Symposium (Asien- und Afrika-Studien 29 der Humboldt Universität zu Berlin), edited by Florian C. Reiter, 198, note 62.

20 These are the seven visible stars of ursa major (Great Dipper). A second column has the seven religious taboo names (hui 諱). All are written with the radical gui 鬼, "demon." 
as if you have the decree of the Perfected King of Shenxiao Heaven (fenghuo shen e jisu zhuizhuo jiji ru shenxiao zhenwang chi 風火神惡疾速追捉急急 如神霄真王敕)/

[Zhao Gongming,] your radiant halo is brilliant, and its light defeats the hordes of demons (yuanguang huangyao zhaobai moqun 圓光晃耀照敗魔 群). ${ }^{21}$

Again, it is important to remember that the priest recites the information given in the dissolved amulet at the moment he writes the amulet. The phrases and statements characterize the respective Thunder divinity.

In this case the priest has first united his own spirit potential with the cosmic Marshal Zhao Gongming to be in position to address spirit troops and issue orders. How could this be done? We find for example in the canonical collection of exorcist rituals, A Corpus of Daoist Rituals (Daofa huiyuan 道法會元) of the fourteenth to fifteenth century during the Ming period (1368-1644), a revealing description of such a meditation that leads to the required spiritual transformation. ${ }^{22}$ A magic spell of fourteen characters in pseudo-Sanskrit either precedes or concurs with the meditation. ${ }^{23}$ The spell resists translation, and then we read:

You concentrate your meditation on the sound of Thunder that arises at the Window of Earth (dihu 地戶) in a terrifying manner. Concentrate in meditation on the Marshal [Zhao Gongming] who from the Gate of Heaven (tianmen 天門) descends and stands at the Window of Earth. In the following procedure you swallow the fire of the heart and let it unite and wed the water of the kidneys in the Central Palace (zhon-gong 中宮). Concentrate your meditation on the ancestral breaths (zuqi 祖氣) that rise upward following the spine up to the Mud-Pill Palace (niwan gong 泥丸宮) where they visit the God-emperors of Shenxiao Heaven

21 TT 1220: 236.11a-12a.

22 Concerning the title, A Corpus of Daoist Rituals, see Kristofer Schipper and Yüan Ping-ling, in Kristofer Schipper and Franciscus Verellen, eds., The Daoist Canon, A Historical Companion to the Daozang (Chicago: University of Chicago Press, 2004), 1105-13.

23 Chinese pseudo-Sanskrit characters are new magic signs of sound that combine generally known characters. In this case all characters have the radical mouth (kou 口) that is combined with other characters to indicate the pronunciation-but the sense remains secret.
(Shenxiao dijun 神霄帝君). You exhale the breaths that resemble a pearl of fire, which is vast and appears to have the shape of a wheel of fire. You use the Sword Mūdra (jianjue 劍訣) to cut open [that pearl of fire] and see the blaze of fire peeling off, and you also see the Marshal who stands at the Window of Earth and becomes a single entity with yourself as marshal (ziji yuanshuai 自己元帥. ${ }^{24}$

We keep in mind that the priest can transform himself into such a Thunder divinity if he had been initiated to receive the respective register ( $l u$ 鉒). He acts then on the basis of his initiation into this or that tradition of Thunder rituals; this enables him to adopt the respective divine alter ego that will evolve from within his own body and mind. There is no spirit-possession involved: that would imply that a divinity descends upon the person from the outside and takes possession of the person. We know that spirit possession is a characteristic feature of shamanism, which differs totally from religious Daoism and Daoist exorcism. In the course of history, Daoists had to make unceasing and strenuous efforts to convince the Chinese intelligentsia and the imperial administration that Heavenly Masters Daoism with all its exorcist proficiency must not be taken for shamanism. ${ }^{25}$

What do we know about the Thunder divinity Zhao Gongming? The canonical Report on the Marshal Zhao [Gongming] says that Zhao Gongming incarnated Brahma breaths that would make him a divinity of Anterior Heaven (xiantian 先天). ${ }^{26}$ However, the same canonical Report also claims to have examined Zhao Gongming to find out that he lived on earth around the end of the Zhou period (third century BCE). He evaded the Qin administration (秦, 255-209 BCE) and toiled to accomplish Daoist self-cultivation. Finally he received the divine call to advance to the rank of Thunder divinity. This story could be understood as an attempt to justify the divine status of Zhao Gongming on the basis of a successful Daoist life in the world of man, which

24 TT 1220: 234.7b-8a. This is only one example taken from a row of spells and descriptions of appropriate meditation. The compilation collects materials that belong to the cult of Zhao Gongming.

25 See Florian C. Reiter, Grundelemente und Tendenzen des Religiösen Daoismus, das Spannungsverhältnis von Integration und Individualität in seiner Geschichte zur Chin-, Yüan- und Frühen Ming-Zeit (Münchener Ostasiatische Studien 48) (Stuttgart: Steiner-Verl. Wiesbaden, 1988), 40 and note 90.

26 TT 1220: 232.1a-2b. 
would associate him with the category of Posterior Heaven (houtian 後天).

Since the Song period Daoist theoretical expositions distinguish different existential qualities that were called: Anterior Heaven and Posterior Heaven. Of course, this fundamental issue also pertains to the sphere of the divine. ${ }^{27}$

Many glorious divine titles in the Thunder pantheon are accompanied by personal names, which suggest an ascent from a human existence to life in the spheres of the divine. Zhao Gongming is a fine example to show that both categories, Anterior Heaven and Posterior Heaven, easily merge into a single name. The notions of Anterior Heaven and Posterior Heaven represent oscillating categories that are not at all irreconcilably opposing positions. This situation describes a basic condition of Thunder divinities. The many standard and divine functional titles, for example, the divinities of the five directions, were eventually combined with different personal names, which may well reflect a specific local or regional background. This reminds us of a basic feature of Daoism. The many names of Laozi ( 老子) or Taishang Laojun (太上老君) that we find, for example, in the Han-era Scripture of the Transformations of Laozi (Laozi bianhua jing 老子變化經), may represent the names of leaders in the many local Daoist centers that must have flourished during the Han period. ${ }^{28}$ These leaders may have been seen as incarnations or representatives of Taishang Laojun. There is no point in assuming that those names were naïve pious fiction. In this way the later and regionally widely scattered Thunder traditions evolved within the frame of historical Heavenly Masters Daoism.

There is another important aspect that we must explore: Thunder divinities are believed to staff a celestial administration that gives the priest and spirit administrator the chance to deliver addresses and submit literary petitions. We may look at such a spirit administration following a description offered by Wang Wenqing. Here we study parts of chapter 56 in A Corpus of Daoist Rituals that reveal some ritual implications:

The Headquarter Office of Thunder and Thunderclaps (leiting dusi 雷霆都司) is the Special

27 See Reiter, Man, Nature and the Infinite, 8-31 (Part I: Aspects of the Pantheon in Thunder Magic).

28 For this text see Anna Seidel, La divinisation de Lao tseu dans le Daoisme des Han (Paris: École française d'Extrême-Orient, 1969).
Control Office (zhuansi 專司) of the God-emperor of the North (beidi 北帝) that arranges the ranks of officials, distributes their individual duties, and assists the governance of the Jade Pivot. ${ }^{29}$ Whenever in the world floods cause inundations [or] drought-demons [operate], in each case you ask the Court of the Jade Pivot (yushu yuan 玉樞院) that the respective reports [about the disasters] be listened to and that action be taken. As to the battle-axes and halberds of Thunder and thunderclaps, as to applause, reward, and punishment, they all have their regulations and are not in confusion. Officials are in charge of all relevant matters....

In addition there is the Penglai Office (Penglai $s i$ 蓬萊司), controlled by the Assistant Commissioner of the Waters. His generals and emissaries are specialized to administer the duties concerning water. They distribute clouds, scatter the breath, and equally [take care of] the [Chang]jiang, the sea, the $[$ Huang]he, the marshes, the springs, and fountains. When excessive heat occurs in the world, you must report to the Court of the Jade Pivot. You pray and memorialize the request that heavy rain and soaking moisture may be sent down to save the people....

The persons who study perfection and receive ritual methods (feng $f a$ 奉法) all request [the service of Thunder] troops in accordance with their orderly divisions. On the occasion of the transmission of [ritual] norms (chuanke 傳科) one should obtain proper knowledge concerning the Divine Ranks of Thunder and Thunderclaps (leiting shenwei 雷霆神位)..$^{30}$

The information is clear: the well-organized administration is staffed with responsible divine officers. It is not difficult to recognize ways of thinking that characterize the Chinese secular administration. ${ }^{31}$ The text does not refer to the categories of Anterior Heaven

29 The text uses the term "Jade Initiatory Force," or perhaps "Jade Chi [Military Office]" (yuji 玉機), which most certainly is a mistake. The phrase occurs nowhere else. I believe we should read yushu zhi zheng 玉樞之政 as translated.

30 TT 1220: $56.4 \mathrm{~b}$. This refers to the initiation as priest and thunder specialist in the context of Heavenly Masters Daoism.

31 Perhaps the best documentation is Charles O. Hucker, A Dictionary of Official Titles in Imperial China (Stanford: Stanford University Press, 1985). 
and Posterior Heaven, but neither does it allow us to connect the Thunder divinities and spirit officials with human proper names, which might have suggested that the spirit officials in consideration had posthumous careers as divinities. In fact, the presentation remains part of the abstract top level of Anterior Heaven.

We learn that the divine realm of the Thunder administration keeps a keen eye on what is going on in the world, and we learn how the Daoist priest becomes involved. He has to perform the liturgical task of dispatching memorials to the Thunder administration, acting on behalf of individual clients or communities. We retrieve some more information about the spirit administration:

The Divine Thunder (shenlei 神雷) has hundreds of officials and thousands of generals, who reside in the centre of the three realms (sanjie 三界). They are all stationed (dunzhu 屯駐) in accordance with the seasons, and on behalf of heaven they operate and exert their transforming influences. In one year and within the four seasons [the Divine Thunder] issues paroles (fahao 發號) and dispatches orders (shiling 施令) to spread rain and moisture evenly. In the case that [people in] the lower regions were neither loyal nor pious, neither humanitarian nor faithful (zhong-xiao-ren-yi 忠 孝仁義), and [either] in their former lives [or] in their present time harmed creatures in hideous ways and unjustly amassed properties, the Three Officials (sanguan 三官) hand in [appropriate] reports to the higher [institutions in heaven] and have the [respective] names registered in the Files of the Wicked ( $e^{\prime} b u$ 惡簿). ${ }^{32}$ The superior god-emperors order the Divine Thunder to crusade against [the guilty ones]. Perhaps today, when wild winds and heavy rain occur and the terrifying sounds of Thunder punish and kill men and creatures, this is just such an event. If you desire to activate the Divine Thunder, you must send a report to the Three Monitoring Offices (sansi 三 司) and cause memorials to soar up to the nine pure [heavens] (jiuqing 九清). It is then that you can employ the Divine Thunder. ${ }^{33}$

32 Zhong-xiao-ren-yi are traditional Confucian ideals and virtues.

33 TT 1220: 56.13b, compare Florian C. Reiter, Basic Conditions of Daoist Thunder Magic (Abhandlungen für die Kunde des Morgenlandes 61) (Wiesbaden: Harrassowitz, 2007), 82.
The listing of Divine Ranks of Thunders and Thunderclaps (leiting shenwei 雷霆神位) in chapter 56 of A Corpus of Daoist Rituals displays a fascinating pantheon. ${ }^{34}$ A very short introduction is offered here: The Divine Ranks of Thunders and Thunderclaps give the supreme position to the Heavenly Ruler, the God-emperor and Lord of the Six Pāramitās (Liubo tianzhu dijun 六波天 主帝君). ${ }^{35}$ Only this Heavenly Ruler and Lord holds the rank of God-emperor. The supreme position is paired with the Five Thunder emissaries of the chancellor in the Jade Department (yufu shangqing wulei shi 玉府上 卿五雷使). The group of Thunder Lords that represent the five directions follow immediately after the True Lord of the Court of the Jade Pivot (Yushu yuan zhenjun 玉樞院真君). ${ }^{36}$ They precede a long listing of divinities that are further qualified by official titles, such as administrator, chancellor, and Heavenly Master. There are many emissaries, immortal masters, ritual masters, marshals, and judges. We note that martial ranks like the Thirty-Six Stalwarts of the Thunder Drums (Sanshiliu leigu lishi 三十六雷鼓力士) and various spirit generals complete the listing. ${ }^{37}$

Some of the names allude to famous traditions, like the mighty divinity with glaring eyes and silver teeth that controls the thunderclaps and the radiance of fire (zhang pili huoguang yinya yaomu weishen 掌霹靂火光 銀牙耀目威神). The divinity is in fact a certain Deng Bowen (鄧伯溫), who had become the Great Divinity of Blazing Fire (Yanhuo dashen 炎火大神). ${ }^{38}$ The figure of Deng Bowen again oscillates between the categories of Posterior Heaven and Anterior Heaven as shown by his canonical biographies show. ${ }^{39}$ However, we will not continue to present this theme.

The Thunder specialist who happens to follow the exorcist tradition of the Divinity of Blazing Fire must evolve Blazing Fire out of himself and adopt the divinity as his alter ego in order to execute ritual tasks. Wang Wenqing featured the visualization of the divinity and

\footnotetext{
34 TT 1220: 56.5a-10a.

35 Concerning the divinity see also TT 1220: 122.1a. See F.C.Reiter, Man, Nature and the Infinite, The Scope of Taoist Thunder Magic Rituals (Abhandlungen für die Kunde des Morgenlandes 81) (Wiesbaden: Harrassowitz, 2013), 12. See below note nr.43, concerning another Buddhist import: the divinity Heavenly Mother Marici.

36 TT 1220: 56.5a.

37 TT 1220: 56.9 a

38 TT 1220: 56.6a.

39 TT 1220: 56.14b-15a. See Florian C. Reiter, Basic Conditions of Daoist Thunder Magic, 85-6.
} 
spirit transformation in the tract Assemble the Divine Force (Lianshen 鍊神), which reads as follows:

Let your divine forces coalesce and sit quietly in meditation. Concentrate on the one most shining point in the Kidney Palace (shengong 腎宮). Within a short time, fire arises, gradually engulfing your body. You blow one load of breath from your mouth, and the ashes are altogether blown away. Then, you concentrate on the breaths in the five colors of the five directions, which mix and combine to shape a single united aura of radiant shining in purple and golden colors; this [aura] transforms itself into an infant (yinger 嬰兒) that gradually grows big. [This image] has the beak of a phoenix with silver teeth, red hair, and a body shaped like a quail. Both eyes shine fiercely, penetrating [a distance] of ten thousand feet (zhang 丈). Both wings shine like fire. On both forelegs, a head with eyes emerges. Each of them also emits a shining fire. The belt has the colour of gold. The left hand clutches a fire auger and the right hand clutches an eight-faceted mallet. A fiery dragon winds around the body. ${ }^{40}$ Thereupon you concentrate and see yourself as this Divine General of the Five Thunders. His head touches the heaven, and he stands on the earth. Close around him there are fiery clouds that wrap him with the divine and fierce might of blazing fire. This is "Blazing Fire," the Heavenly Lord Deng (Yanhuo Deng tianjun 炎 火鄧天君) who is the ruling and commanding divinity in the rituals of the fire chariots. ${ }^{41}$

Whatever the description of a Thunder divinity may contain, the priest must merge in person with the divinity as his alter-ego so as to reach an equally divine status and the resulting cosmic might. ${ }^{42}$ This is the pre-

40 TT 1220: 80.1a-1b (Yanhuo lüling Deng tianjun dafa 炎火律令鄧天 君大法) shows a very good example for later (probably thirteenth century) addenda and embellishments of the status symbols of this divinity. The divinity is said to have, among other characteristics, "three eyes," and below the two wings are "two heads. The left one is in charge of the wind, and the right one is in charge of the rain. The whole body of the divinity is engulfed in fierce fire, and he rides a red dragon." There is no exclusive canon of such marks of identity, which religious imagination freely molds and enlarges on the basic pattern of the body of a quail.

41 TT 1220: 124.1b-2a.

42 In the thirteenth to fourteenth century the cult of the Heavenly Mother Marici (Molizhi 摩利支) developed, also in the context of condition for operating Daoist exorcist rituals. The separation of man and the divine melts away in the event of Thunder Magic rituals.

It is worthwhile considering some general and basic aspects of the world of the divine and the demoniac in Daoism. Early Daoism already produced conclusive books such as the Demon Law of the Lady in Blue (Nüqing guilü 女青鬼律), possibly dating to the third century, which reveals particularities of the demons. ${ }^{43}$ The text describes the omnipresence of demoniac potentials that permeate the world and the cosmos. ${ }^{44}$

Nüqing guilü starts out listing demons that are identified by proper human names. They occupy the astral constellations, indicators of the sexagesimal cycle that pairs the ten Heavenly Stems (tiangan 天干) and the twelve Earthly Branches (dizhi 地支). The demons fulfill clearly defined tasks. For example, the cruel divine demons of the five directions administer the killing of people. Two more examples include the cruel divine demon of the East that is named Jian Jiaozi (堅角子), and the demon of the West, which is named Xie Guzi (邪古子). We learn that the God-emperors deploy the five directional demons, together with other forces, to administer and punish the crimes committed in the world of man. We learn that these demons always dwell amongst people, but that nobody sees them. ${ }^{45}$ By following the Nüqing guilü, the Daoist who knows the names of the demons can ward them off. He may also avoid them by helping the divinities who distribute vital breaths.

Other issues cause common people to wrongly neglect the divinities and focus solely on the demons, since they are afraid of them. ${ }^{46}$ Demons are responsible, for example, for epidemics. We are told that such demoniac interferences are punishments that are deserved since they result from human misbehavior. ${ }^{47}$ Demons were thought

Thunder Magic rituals. It was quite demanding to transform into a female divinity, known as Dipper-Mother (Doumu 斗母), see TT 1220: 85.14b-18a. The divinity Marici is a Buddhist import; compare William E. Soothill and Lewis Hodous, A Dictionary of Chinese Buddhist Terms (Taipei: Cheng Wen Pub. Co., 1972), 435 a.

43 TT 790 Nüqing guilü. See A. Dudink in Schipper and Verellen, eds., The Daoist Canon, A Historical Companion to the Daozang, 127-9.

44 Also see TT 1201 Daoyao lingqi shengui pinjing for a survey on various categories like mountain spirits, see TT 1201: 5a-6b.

45 TT 790: 1.2b, 3a.

46 TT 790: 1.8a, 8b.

47 TT 790: 6.1a sq. 
to be the souls of deceased and possibly malevolent persons who linger as dangerous demons. The notion of a posthumous transcendent carrier does not of course exclusively recognize negative phenomena.

The now familiar scholar and Daoist Wang Wenqing is a fine example of a person of this world who was posthumously allotted the rank of a Thunder divinity. The deified Wang Wenqing certainly fulfilled the category of Posterior Heaven. He was deified in the thirteenth or fourteenth century as Divine General Jiazi Wang Wenqing (Jiazi shenjiang Wang Wenqing 甲 子神將王文卿). ${ }^{48} \mathrm{Jia}$ and $z i$ are the first positions of the Heavenly Stems and Earthly Branches, and represent the traditional sexagesimal cycle of time that indicates the comprehensive cosmic might of the Divine General Wang Wenqing.

Many centuries earlier, the Nüqing guilü listed the name Radiance of Origin (Yuanguang 元光) for the demon in charge of Jiazi days. ${ }^{49}$ Here the troupe of sixty demons comprised sixty persons dedicated to killing. They have human bodies, red hair, and wear no garments. They have ears but no eyes, and can soar rapidly for distances of one thousand miles. In human life they had committed murderous crimes, were not filial, and now are committed to harming people. If one keeps their names in mind all day long, these demons do not dare to approach the respective persons..$^{50}$

Centuries later, from the Song period onward, the Thunder divinities handled the same responsibilities that the Nüqing guilü had attributed to demons. The Thunder divinities were now in charge of human conduct and accordingly administered punishment.

In the Song period, a Thunder divinity was explained as internal, bodily reality. We have seen that the priest could adopt a divinity as a spiritual alter ego, which

48 TT 1220: 201.14b, 15a. See Florian C. Reiter, "Daoist Transcendence and Thunder Magic, as seen in the Great Rituals of Heavenly Ting of Metal and Fire in the Divine Empyrean (神霄金火天丁 大法)," Zeitschrift der Deutschen Morgenländischen Gesellschaft 161 (2011), 418-19. Also see Robert Hymes, Way and Byway, Daoism, Local Religion, and Models of Divinity in Sung and Modern China (Berkeley: University of California Press, 2002), 154-62. Concerning the combination Chia-tzu, see for example TT 790: $1.4 b$, where the name of the demon in charge of a Jiazi day is The Radiance of Origin (Yanguang 元光).

49 TT 790: 1.4a. For this list also see TT 1201 Daoyao lingqi shengui pinjing 13a-16a. The description of the troupe varies. They lead on the three cadavers (sanshi 三尸), which are disastrous forces in the human body. The demons have a human body but no head at all. And yet, they have ears but no eyes.

50 TT 790: $1.7 \mathrm{~b}$. he could then unite with the respective cosmic counterpart. The united entity of priest and divinity would exert martial might and execute exorcist functions by means of the Thunder amulet.

The Song-era presentations and descriptions as well as the terminology of Internal Alchemy lend the individual Thunder divinity a rather personal dimension. We understand that man creates the god that he is himself. Perhaps it is this aspect that we should keep in mind when we discuss the world of the divine in Daoism.

\section{Bibliography}

\section{SOURCES FROM THE DAOIST CANON (TT):}

Zhengtong Daoang (Daoist Canon), 61 vols. Taipei: Yiwen Company, 1977. The numbers refer to the numbering in the Index Volume of this edition.

TT 223 Qingwei yuanjiang dafa 清微元降大法

TT 772 Taishang Laojun jinshu neixu太上老君金書內序 TT 774 Youlong zhuan猶龍傳

TT 790 Nüqing guilü 女青鬼律

TT 1201 Daoyao lingqi shengui pinjing 道要靈衹神鬼品經

TT 1220 Daofa huiyuan 道法會元

TT 1225 Dongxuan lingbao sanding fengdao kejie yingshi

洞玄靈寶三洞奉道科戒營始

TT 1311 Xianquan ji 峴泉集

TT 1232 Daomen shigui 道門十規

TT 1241 Chuanshou sanding jingjie falu lüeshuo 傳授三洞 經戒法鉒略說

Chamberlain, Jonathan. Chinese Gods. Hong Kong: Long Island Publishers, 1983.

Giles, Herbert A. A Chinese-English Dictionary, reprint edition. Taipei: Cheng Wen Publishing Co., 1972 (London, 1912).

Grube, Wilhelm. Die Metamorphosen der Götter. Leiden: E.J. Brill, 1912.

Hucker, Charles O. A Dictionary of Official Titles in Imperial China. Stanford: Stanford University Press, 1985.

Hymes, Robert. Way and Byway, Daoism, Local Religion, and Models of Divinity in Sung and Modern China. Berkeley: University of California Press, 2002.

Keupers, John. "A Description of the Fa-chang Ritual as Practiced by the Lü Shan Daoists of Northern Taiwan." In Buddhist and Daoist Studies I. Edited by Michael Saso and David W. Chappell, 82-92. Honolulu: University of Hawai'i Press, 1977. 
Lin, Chen-yüan 林振源. “Le ritual Daoiste du sud-est du Fujian.” PhD diss., EPHE, 2014.

Kubo Noritada 窪徳忠. Daojiao zhushen 道教諸神. Chengdu: Sichuan renmin chuban she, 1996.

Reiter, Florian C. Grundelemente und Tendenzen des Religiösen Daoismus, das Spannungsverhältnis von Integration und Individualität in seiner Geschichte zur Chin-, Yüan- und Frühen Ming-Zeit (Münchener Ostasiatische Studien 48). Stuttgart: Steiner-Verl. Wiesbaden, 1988.

_ . transl./ed. Leben und Wirken Lao-Tzu's in Schrift und Bild, Laojun bashiyi hua tushuo (老君八十一化圖說). Würzburg: Königshausen \& Neumann, 1990.

- The Aspirations and Standards of Daoist Priests in the Early T'ang Period (Asien- und Afrika-Studien 1 der Humboldt-Universität zu Berlin). Wiesbaden: Harrassowitz, 1998.

"A Preliminary Study of the Daoist Wang Wen-ch'ing (1093-1153) and his Thunder Magic (lei-fa)." Zeitschrift der Deutschen Morgenländischen Gesellschaft 152 (2002): $155-84$.

_. Basic Conditions of Daoist Thunder Magic (Abhandlungen für die Kunde des Morgenlandes 61). Wiesbaden: Harrassowitz, 2007.

. "The Management of Nature: Convictions and Means in Daoist Thunder Magic (Daojiao leifa)." Purposes, Means and Convictions in Daoism, A Berlin Symposium (Asien- und Afrika-Studien 29 der Humboldt Universität zu Berlin), edited by Florian C. Reiter, 183-200. Wiesbaden: Harrassowitz, 2007.

. "Daoist Thunder Magic (Wu-lei fa), Illustrated with the Example of the Divine Protector Chao Kung-ming." Zeitschrift der Deutschen Morgenländischen Gesellschaft 160 (2010), 121-54.

. "Daoist Transcendence and Thunder Magic, as seen in the Great Rituals of Heavenly Ting of Metal and Fire in the Divine Empyrean (神霄金火天丁大法)." Zeitschrift der Deutschen Morgenländischen Gesellschaft 161 (2011): 415-44.

- Man, Nature and the Infinite, The Scope of Daoist Thunder Magic Rituals (Abhandlungen für die Kunde des Morgenlandes 81). Wiesbaden: Harrassowitz, 2013. . “The Discourse on the Thunders 雷說 by the Daoist Wang Wen-ch'ing 王文卿 (1093-1153).” Journal of the Royal Asiatic Society 14/3 (2004): 207-39.

Saso, Michael, and David W. Chappell, eds. Buddhist and Daoist Studies I. Honolulu: University of Hawai'i Press, 1977.

Schipper, Kristofer and Franciscus Verellen, eds. The Daoist Canon, A Historical Companion to the Daozang. Three vols. Chicago: University of Chicago Press, 2004.
Seidel, Anna. La divinisation de Lao tseu dans le Daoisme des Han. Paris: École française d'Extrême-Orient, 1969.

Soothill, William E., and Lewis Hodous. A Dictionary of Chinese Buddhist Terms. Taipei: Ch'eng Wen Pub. Co., 1972.

Wu Zhen 吳真. Wei shenxing jiazhu, Tang Song Ye Fashan chongbai di zaocheng shi 為神性加注唐宋葉法善崇拜 的造成史. Peking: Zhongguo shehui kexue chuban she, 2012. 